\title{
UK science funds in limbo
}

\section{Public spending cuts leave research councils with hard choices over which fields to support.}

\section{BY GEOFF BRUMFIEL}

$\mathrm{I}$ $\mathrm{n}$ recent months, UK scientists have fretted, lobbied and protested in anticipation of the government's comprehensive spending review - a four-year budget to be unveiled this week that is designed to slash the country's deficit through deep cuts in public spending.

The budget was still being finalized as Nature went to press. But the battle over the cuts has already turned from whether they will happen, to where they will fall. The spending review itself "is only the start of a process", says David Willetts, minister for universities and science. In the months to come, research councils, universities and ultimately scientists themselves will have to make tough choices about what science to pursue in difficult economic times.

"Everybody's been asking what's next," says Jennifer Rohn, a cell biologist at University College London and the organizer of Science is Vital, a grassroots group protesting against the cuts that sprang up in September (Nature is an official supporter of the campaign).

The seven research councils - which deliver about half of UK public research funding (see 'How UK science is funded') - will finalize different scenarios for accommodating the budget reductions. They are unlikely to skim evenly across all areas of science, and instead will probably cut funding from some fields to preserve others. The details of the cuts will be worked out in negotiations between the

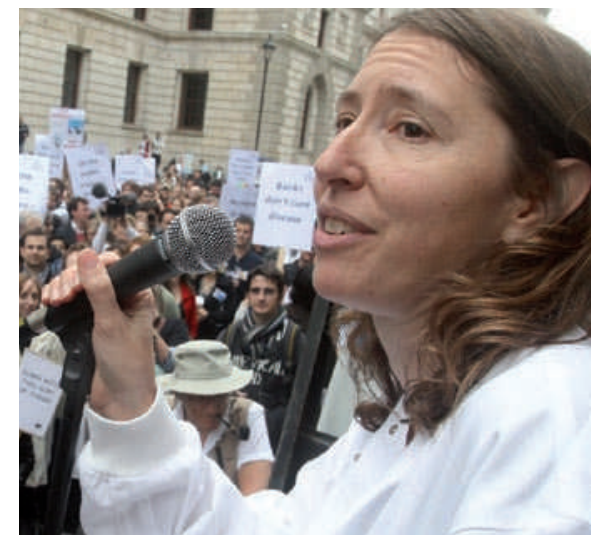

Jennifer Rohn has rallied scientists to fight the cuts.

Department for Business, Innovation and Skills, which oversees science spending, and the research councils.

Although the councils won't be in direct competition, the process could stir up trouble, says Colin Blakemore, former head of the Medical Research Council who is now at the University of Oxford. "The likelihood of infighting between disciplines is really very great," he says.

The consequences of even small reductions will be significant. Many research councils are heavily committed to running research centres, maintaining equipment and paying for subscriptions to international efforts such as CERN, the European particle-physics lab near Geneva, Switzerland. In any given year, some

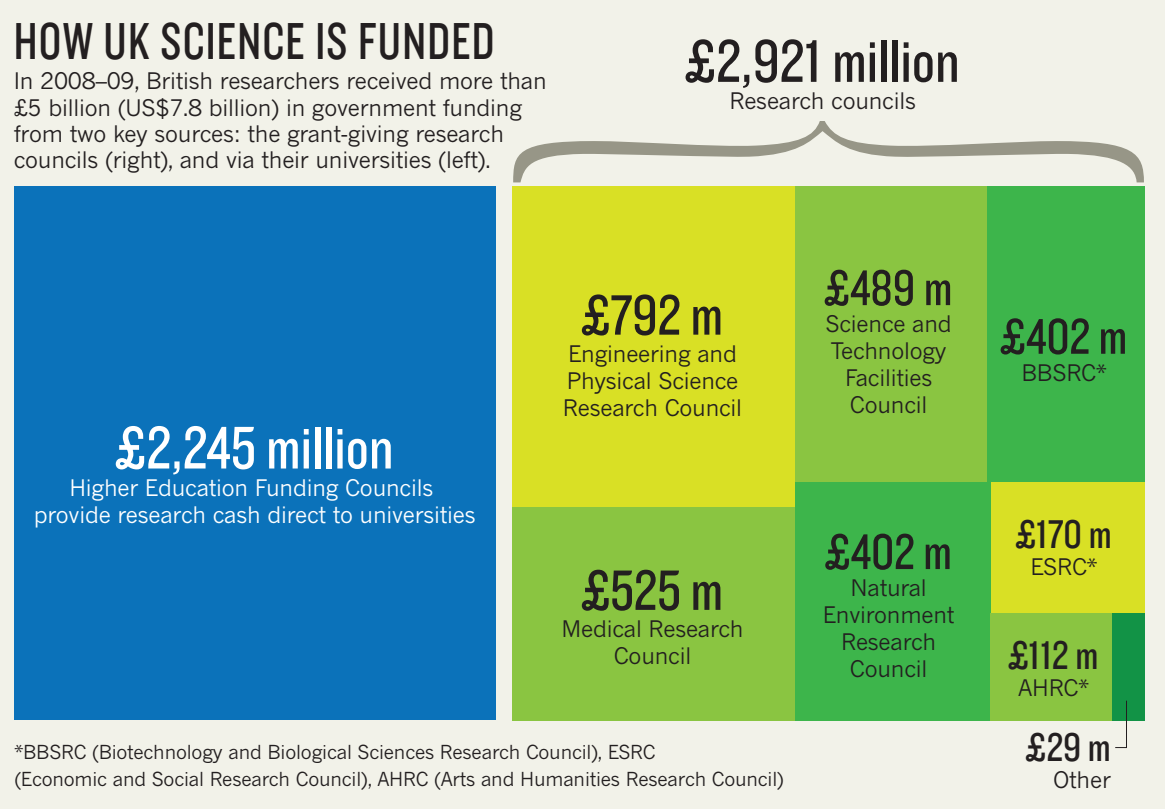

95\% of research-council funding is committed for the following year. That means cuts will fall first and hardest on new grants. Even a small drop could trigger a dramatic fall in already low grant-application success rates (see Nature 464, 474-475; 2010). Meanwhile, universities are facing even more uncertainty following a review of higher education published last week. An independent panel led by BP's former chief executive, John Browne, recommended removing a government cap on tuition fees while slashing teaching subsidies. The plan, expected to be adopted by the government, will lead to an upheaval of university funding and may leave some universities uncertain about their income.

Richard Jones, pro-vice chancellor for research and innovation at the University of Sheffield, says that whole departments could be lost in the struggle to adapt to the new landscape, and science departments, which are costly to run, will make tempting targets. "Unfortunately, there will be fewer institutions that do science in the United Kingdom," he predicts.

Talk of consolidation is also rife in the corridors of government. The hope is that concentrating scientific expertise and facilities will allow researchers to do more with fewer resources. Rohn, however, is sceptical that scientists would be prepared to "make a pilgrimage to the one confocal microscope left in the United Kingdom".

Although this week's spending review acts as a guide for the next four years, it will not lay out specific annual budgets. Blakemore says that uncertainty over future funding may be as damaging as the headline cuts in this week's budget. "The impact of open-ended cuts is far greater than the impact of defined cuts," agrees Imran Khan, director of the Campaign for Science and Engineering in the UK, which advocates for research spending. Khan says that his group will be lobbying hard for a government commitment to increase science spending in step with the gross domestic product in the years following the current budget.

The full impacts of the science budget may not emerge until next year. But decisions may come more quickly for Rohn. Aged 42 and on her third postdoc, she fears her time in research may be coming to an end. "My fellowship runs out in a year's time, and I'm fully expecting not to get a job," she says. "It's heartbreaking because I really want to stay in science." - $\rightarrow$ NATURE.COM How did science fare in the UK spending review? go.nature.com/ripidq 